\title{
Prisoners' Conjugal Visitation Rights in India: Changing Perspectives
}

\author{
Anamica Singh* and Anupal Dasgupta**
}

\section{Abstract}

Right of conjugal visitation remains an old debate which has resurged recently with the Jasvir Singh decision of the Punjab and Haryana High Court. The international community is divided over the boons and banes of such a benefit being extended to convicts. Some construe it as a privilege; the recent trends argue that the same is an extension of our basic human rights, constitutionally enshrined as being inherently 'fundamental' and hence sacrosanct. With the modern penal systems across the globe embracing the Reformative Theory of punishment, the idea that a criminal is a product of the social, economic and environmental conditions is increasingly gaining acceptance. By that logic, a better way to humanize the social ecology within the four walls of the prison and to reform that individual is by allowing conjugal visitation. The article is primarily a stakeholder analysis of the problem, the key stakeholders being the prisoner, his/her spouse, the correctional department and the society. It will further discuss the possible benefits and the setbacks of conjugal visitation, the varied international stance and India's take on the issue in light of the Jasvir Singh judgement. Finally, a determination will be attempted as to whether such a correctional provision is a right arising out of a broad interpretation of Article 21 of our Constitution.

\footnotetext{
* Third Year, BA, LLB (Hons.), RMNLU, Lucknow; anamkasingh94@gmail.com.

** Third Year, BA, LLB (Hons.), RMNLU, Lucknow; anapalbs@gmail.com.
} 
Keywords: Article 21, Conjugal Visitation, Jasvir Singh, Reformative Theory, Right of the Prisoners.

\section{Introduction}

The very recent landmark ruling of the Punjab and Haryana High Court in Jasvir Singh and Ors v. State of Punjab and Ors, ${ }^{1}$ sparks off an old debate. Pioneering the cause, Justice Surya Kant ruled in favour of the prisoners' right to procreation or alternatively artificial insemination. In January of 2010, while hearing a public interest litigation on treatment facilities for HIV positive prison inmates, the Bombay High Court had directed the Maharashtra government to examine the possibility of allowing jail inmates to engage sexually with their wives in privacy within the jail premises. Justice Majumdar in this regard observed:

There may be physical needs. See whether a separate place can be given to a prisoner and his wife for a day or two. The government is spending crores of rupees to curb the AIDS menace in jails. Instead why don't you take preventive steps. ${ }^{2}$

The recent ruling is a wakeup call for policy and decision makers to mine international documents and human rights norms that recognize the necessity of punishment and at the same time outline a standard for the safety of individuals in custody, the protection of human dignity and the acknowledgement of their right to sexual self expression.

\section{Right to Conjugal Visitation in Different Jurisdictions}

A global examination of the problem brings up certain discernible trends. In Europe, for instance, short home leaves for selected classes of prisoners have been established in England, Wales, North

\footnotetext{
1 Jasvir Singh, 2015 (1) R.C.R. (Criminal) 509.

2 Press Trust of India, Why can't Prisoners have Sex in jails, Court asks Maharashtra Govt, The Times of India, (Jan. 14, 2014), available at: http:/ / timesofindia.indiatimes.com/india/Why-cant-prisoners-have-sexin-jails-court-asks-Maharashtra-govt/articleshow/5445590.cms.
} 
Ireland, Scotland, Denmark, Switzerland, Germany, Greece, and Sweden. ${ }^{3}$

Latin American practices provide for supervised visits of the spouse with the prisoner within the prison. These regulations are in effect in Chile, Puerto Rico, Argentina, and Mexico. Chile encourages even greater permissiveness where provisions are made for both private visits in the prison as well as for home leaves. ${ }^{4}$

Germany allows prisoners and their spouses or partners to apply for conjugal visits. However, prisoners are searched before being allowed a visit. ${ }^{5}$ In the Russian penal system, since the campaign for prison reform that began in 2001, prisoners get extended onsite family visits, approximately once per month. ${ }^{6}$

In the United States of America, prisoners in federal custody are denied conjugal visits while for those in state custody, conjugal rights are governed by the law of that particular state. States like California, New York, Washington and Connecticut allow conjugal visitation programs which are now known as extended family visits or family reunion visits. It aims at strengthening family ties and rehabilitation.

${ }^{3}$ Ruth S. Cavan \& Eugene S. Zemans, Marital Relationships of Prisoners in Twenty-Eight Countries, 49(2), J. CRIM. L. CRIMINOLOGY \& POLICE SCI., 185 (1958).

${ }^{4}$ Id. at 186.

${ }^{5}$ Deutsche Manipulationskunst, Gefälschte Abgaswerte von VW in den USA, Spiegel Online, available at:

http://www.spiegel.de/international/germany/0,1518,688736,00.html. (last visited on Sep. 14, 2015).

${ }^{6}$ Giles Whittell, After the Gulag conjugal visits computers and a hint of violence, THE TIMES, Jun. 2, 2006. 


\section{Jasvir Singh and Ors v. State of Punjab and Ors}

\section{Summary of Facts}

The petitioners, husband and wife, were tried for the offences under Section 302, 364A, 201 and120-B of the Indian Penal Code, for kidnapping and brutally murdering a 16 year old minor for ransom. The trial court awarded them death sentence. The honourable Supreme Court dismissed their criminal appeal but commuted the death sentence to life imprisonment for the wife. The petitioners then sought enforcement of their perceived right to have conjugal life and procreate within the jail premises. They sought for a direction to be given to the jail authorities to allow them to stay together and resume their conjugal life for the sake of progeny and make all arrangements needed in this regard. They were also open to 'artificial insemination'.

\section{Issues Involved}

The pivot of the debate rests on Article 21 of the Constitution of India. The 'right to life', as contended has two essential ingredients, namely, (i) preservation of cell; and (ii) the propagation of species of which conjugation is a vital part. In State of Andhra Pradesh v. Chalaram Krishna Reddy, ${ }^{7}$ it was held that a prisoner in spite of incarceration as a convict or under trial continues to enjoy certain fundamental rights which include the right to life. Equally significant is the international perspective on the right to conjugal life in the precincts of jail', which too calls for discussion.

The petitioner's contention was opposed by the State of Punjab, essentially on the plea that the Prisons Act, 1894 contains no provision to permit 'conjugal visitation'; Section 27 of the Act rather mandates proper segregation of male and female prisoners.

The alternative solution of 'artificial insemination' was also considered redundant as according to the affidavit dated November 20, 2010 there existed no such provision in the Prisons Act, 1894 or in the Punjab Jail Manual to allow the convicts

${ }^{7}$ Chalaram Krishna Reddy, (2000) 5 S.C.C. 712. 
(husband and wife) to be in the same cell in the jail or to allow for artificial insemination. ${ }^{8}$

\section{Judicial Determination}

1. Right to procreation survives incarceration. Such a right is traceable and squarely falls within the ambit of Article 21 of the Constitution read with the Universal Declaration of Human Rights, 1948.

2. The penological interest of the State ought to permit the creation of facilities for the exercise of right to procreation during incarceration, may be in a phased manner, as there is no inherent conflict between the right to procreate and incarceration. However, the same is subject to reasonable restrictions, social order and security concerns.

3. The 'right to life' and 'personal liberty' guaranteed under Article 21 of the Constitution include the right of convicts or jail inmates to have conjugal visits or artificial insemination (in alternate). However, the exercise of these rights is to be regulated by procedure established by law and is the sole prerogative of the State.

4. Ordinarily, all convicts, unless reasonably classified, are entitled to the right to procreation while incarcerated. Such a right, however, is to be regulated as per the policy established by the state which may deny the same to a class or category of convicts, as the aforesaid right is not an absolute right and is subject to the penological interests of the State.

5. Finally, the establishment of a Jail Reforms Committee was ordered which will suggest methods to implement 'conjugal visitation' in prisons and also suggest any reasonable classification that needs to be considered while granting such rights to the prisoners.

8 Jasvir Singh and Ors v. State of Punjab and Ors, 2015 (1) R.C.R. (Criminal) 509. 


\section{Right to Conjugal Visitation under Article 21 of the Constitution}

The desire for sexual intimacy and sexual expression is powerful and survives imprisonment. Individuals in custody, despite society's view, maintain their humanity and personhood. As Judge Posner has written, "We must not exaggerate the distance between 'us,' the lawful ones, the respectable ones, and the prison and jail population; for such exaggeration will make it too easy for us to deny that population the rudiments of humane consideration." 9

In D. Bhuvan Mohan Patnaik \& Ors v. State of Andhra Pradesh \& Ors ${ }^{10}$ it was held by the honourable Supreme Court that convicts are not to be completely stripped of the fundamental rights that they possess otherwise, though incarceration denudes certain fundamental rights like the right to move freely, engage in profession of their choice etc. Nonetheless, the convict is entitled to the other constitutional guarantees which are not affected by incarceration, including those under Article 21.

Further, in the much debated case of Sunil Batra v. Delhi Administration \& Ors $^{11}$ (popularly referred to as Sunil Batra I), the honourable Supreme Court, marching far ahead of its time, held:

$[\mathrm{P}]$ ositive experiments in re-humanizationmeditation, music, arts of self-expression, games, useful work with wages, prison festivals, sramdan and service-oriented activities, visits by and to families, even participative prison projects and controlled community life, are among the rehumanization strategies which need consideration. Social justice, in the prison context, has a functional versatility hardly explored.

The judgment in Sunil Batra12 (popularly known as Sunil Batra-II) that followed, brought several radical changes as to how a prison is to be run, like (i) separation of under-trials from convicts in jails; (ii) their right to invoke Article 21 of the Constitution; (iii) separation

${ }^{9}$ Johnson v. Phelan, 69 F.3d 144, 152 (1995).

${ }^{10}$ D. Bhuvan Mohan Patnaik, (1975) 3 S.C.C. 185.

11 Sunil Batra-I, (1978) 4 S.C.C. 494.

${ }^{12}$ Sunil Batra v. Delhi Administration, (1980) 3 S.C.C. 488. 
of young inmates from adults; (iv) liberal visits by family and friends of prisoners; (v) ban on confinement in irons; (vi) The duties and obligations of the courts with respect to rights of prisoners etc. In this regard it was held by the court that:

Visits to prisoners by family and friends are a solace in insulation; and only a dehumanised system can derive vicarious delight in depriving prison inmates of this humane amenity. Subject, of course, to search and discipline and other security criteria, the right to society of fellow-men, parents and other family members cannot be denied in the light of Article 19 and its sweep.

The Andhra Pradesh High Court in G. Bhargavi, Hyderabad v. Secy., Home Dept., Hyderabad and Others ${ }^{13}$ dealt with an identical issue wherein a direction was sought to take immediate steps and allow conjugal visits to spouses of prisoners in jails across the State of Andhra Pradesh. The court rejected the claim observing that if conjugal visits are to be allowed keeping in view good behaviour of the prisoners, chances of the environment in the jail getting disturbed cannot be ruled out as it will have an adverse impact on the other inmates of the jail who have not been selected and extended such benefit. ${ }^{14}$ It was also observed that, "It is not that there is no provision in the Rules to release the prisoners to enable them to lead family life with their spouses when they are granted furlough/leave of course for a limited period." 15

The vital issue of the 'best interests of unborn child of the petitioners' was effectively raised in R. D. Upadhyay v. State of Andhra Pradesh $\mathcal{E}$ Ors., ${ }^{16}$ which dealt with the welfare of women prisoners and the negative effects of prison environment on them. The honourable Supreme Court took notice of the report prepared

${ }_{13}$ Ms. G. Bhargavi, 2012 (5) A.L.D. 432.

${ }^{14} \mathrm{Id}$.

$15 \mathrm{Id}$.

${ }^{16}$ R. D. Upadhyay, (2007) 15 S.C.C. 337. 
by the Tata Institute of Social Sciences on the situation of children of prisoners which suggested that the environment therein was not conducive to the upbringing of a child.

In keeping with all the above, they found the balance in favour of keeping Article 21 intact, in spite of incarceration.

\section{Comparative Practices in Other Jurisdictions}

The United Nations' Basic Principles for the Treatment of Prisoners, 1990 states that:

Except for those limitations that are demonstrably necessitated by the fact of incarceration, all prisoners shall retain the human rights and fundamental freedoms set out in the Universal Declaration of Human Rights, and, where the State concerned is a party, the International Covenant on Economic, Social and Cultural Rights, and the International Covenant on Civil and Political Rights and the Optional Protocol thereto, as well as such other rights as are set out in other United Nations covenants.

In Sherman Block v. Dennis Rutherford, 17 pre-trial detainees challenged the jail policy of denying contact visits with their spouses, relatives, children and friends and also challenged the practice of conducting irregularly scheduled shakedown searches of individual cells in the absence of cell occupants. The District Court of California sustained both the challenges and the Court of Appeals upheld it. The United States Supreme Court however, disagreed and by majority held that a blanket prohibition on contact visits with pre-trial detainees, is a reasonable non-punitive response to the legitimate security concern and does not violate the Fourteenth Amendment to the US Constitution. The Court held that the Constitution does not require that detainees be allowed contact visits when responsible, experienced administrators have determined in their sound discretion that such visits will jeopardize the security of the facility. Justices Marshall, Brennan and Stevens

17 Sherman Block, 468 U.S. 576. 
in their dissenting view nonetheless recognized the value of what the pre-trial detainees asserted and observed that "the ability of a man to embrace his wife and his children from time to time during weeks or months while he is awaiting trial, is a matter of great importance to him."

Dickson v. The United Kingdom, ${ }^{18}$ a decision rendered by the Grand Chamber of the European Court of Human Rights (ECHR) has been cited often. It was a case where two British nationals sought permission for access to artificial insemination facilities. The first applicant was a murder convict and was sentenced to life imprisonment. He had no children. He met the second applicant while she was also imprisoned. She had since been released. The applicants got married in 2001. As they wished to have a child, the first applicant applied for facilities for artificial insemination to which the second applicant also joined. Dickson(s) alleged violation of Articles 8 and 12 of the European Convention on Human Rights which, inter alia, provides that (i) everyone has a right to his private and family life and (ii) that men and women of marriageable age have the right to marry and to find a family, according to the national laws governing the exercise of that right. The Grand Chamber of ECHR held that Article 8 was applicable to the applicants' as the refusal of artificial insemination facilities concerned would go against their right to become genetic parents. The Court then awarded monetary compensation to the applicants on the strength of Article 41 of the Convention which enables it to afford just satisfaction to the injured party.

In a contrasting decision in $R \mathrm{v}$. Secretary of State for Home Department, ${ }^{19}$ the Supreme Court of Judicature (Civil Division), United Kingdom considered the claim of a convict appellant who was serving life sentence for murder. He was aggrieved at the denial of access to facilities for artificial insemination of his wife. The Court considered the appellant's claim in the context of violation of Articles 8 and 12 of the European Convention on

18 Dickson, (2007) 46 E.H.R.R.

${ }^{19}$ R v. Secretary, [2001] E.W.C.A. Civ. 472. 
Human Rights and after referring to the Strasbourg Jurisprudence and relevant decisions of the Commission, it summarized its conclusions as follows:

i. The qualifications on the right to respect for family life that are recognised by Article 8(2) apply equally to the Article 12 rights.

ii. Imprisonment is incompatible with the exercise of conjugal rights and consequently involves an interference with the right to respect for family life under Article 8 and with the right to find a family under Article 12.

iii. This restriction is ordinarily justifiable under the provisions of Article 8(2).

iv. In exceptional circumstances it may be necessary to relax the imposition of detention in order to avoid a disproportionate interference with a human right.

v. There is no case which indicates that a prisoner is entitled to assert the right to find a family by the provision of semen for the purpose of artificially inseminating his wife.

The Court nonetheless put a cautious note that the above reproduced conclusions need not be construed to justify preventing a prisoner from inseminating his wife artificially or naturally. The Court was of the view that interference with fundamental human rights must always involve an exercise in proportionality.

The Court in the above cited case thereafter referred to the policy of the Secretary of State and culled out three reasons for sustenance of the policy that restricts the provision of facilities for artificial insemination, namely:

i. it is an explicit consequence of incarceration that prisoners should not have the opportunity to beget children whilst serving their sentences, save when they are allowed to take temporary leave; 
ii. there is likelihood of a serious and justified public concern if prisoners continue to have the opportunity to conceive children while serving sentences; and

iii. there are disadvantages of single parent families.

The Court thus held that the refusal to permit the appellant the facilities to provide semen for artificial insemination of his wife was neither in breach of the convention nor unlawful or irrational.

The learned amicus curiae in the present case of Jasvir Singh ${ }^{20}$ very aptly suggested that -

The solitary purpose behind travelling into global case law on the point in issue is to assimilate the broad consensus that has emerged on judicial platforms. It may be seen that from U.S. to Europe, the rights to conjugal visits, procreation or even artificial insemination facilities have been recognized only partially, being integrally embedded in Articles 8 \& 12 of the European Convention on Human Rights or as the rights that are fundamental to the liberty and human dignity emanating from the Eighth Amendment, and further subject to the justifiable and proportionate restrictions.

It is hence an indicator to the divided stance of the international community. While some understand the circumstances as a gross contravention of human rights, others justify such checks to be necessary for penological interests and fall under the restrictions to the aforementioned constitutional guarantees.

${ }^{20}$ Jasvir Singh and Ors v. State of Punjab, 2015 (1) R.C.R. (Criminal) 509. 


\section{Rights of the Spouse in Favour of Conjugal Visitation}

The desirability of conjugal visits is a question that could and should be answered by the prisoner's spouse. To deny conjugal visits to any spouse who wants them should be considered a denial of that person's civil and human rights. While most writers have dealt with the subject from the standpoint of prisoners' rights, the legal approach to the question of conjugal visits based on the rights of the prisoner's spouse appears to be overlooked. ${ }^{21}$

Imprisonment of married convicts or under trial is tantamount to simultaneous punishment of their families. Unfortunately, social rejection of the inmates' families is seldom an issue. However, financial and emotional instability, and problems relating to sexual frustration as a consequence of incarceration are prevalent. This privation is a punishment in itself, the victims of which are all innocent in the eyes of law, but their fundamental rights are being violated. It can also be viewed as nothing but a collateral damage since incarceration is necessary. However, allowing conjugal visits to the prisoner's spouse can be the first step to lessen the hardships on their families.

Denial of conjugal rights to the offender's spouse is clearly a form of punishment. Such a bar is clearly in contravention to our constitutional guarantees provided under Article 21 of the Constitution i.e. right to life and personal liberty, which extends to our right to procreation and sexual satisfaction. The paramount importance attached to sexual satisfaction in upholding the institution of marriage is evident from the fact that 'impotency' is a valid ground for divorce. There is no gain saying that when the State denies conjugal rights to the offender who has been punished according to the due process of law, no legal problem arises. It is in denying these rights to the offender's spouse, without the due process guaranteed in the Constitution, that the State errs. ${ }^{22}$

While conjugal visitation can be considered a privilege to be extended to a prisoner, when viewed from the point of view of the

21 Donald P. Schenller, Conjugal Visitation - Prisoners's Privilege or Spouse's Right?, 2(2) NEW ENG. J. PRISON. L, 165 (1975).

22 Id. at 168 . 
prisoner's spouse, it seems appropriate to consider it as a civil and human right. To deny the spouse conjugal visits is to deny conjugal rights. To do so, without providing due process to the legally innocent free world spouse, should be considered unlawful. Since other approaches have not brought about the general use of conjugal visits in our prisons, the legal approach may hold some promise for those wishing to advocate this practice despite the judiciary's reluctance to recognize conjugal rights. ${ }^{23}$

\section{Possible Benefits of Conjugal Visitation Rights}

Jail reforms have been the priorities of none. A little improvement in guaranteeing basic human rights, though still far from satisfactory, has happened with the tireless efforts of the Indian judiciary and a constant monitoring through jail inspections by the District and High Courts with due help from the public spirited organizations and individuals from the civil society. There are no comprehensive plans for the rehabilitation and resettlement of convicts, on their release and many of them step out of a dark hole to fall into a darker ditch.

Clinton T. Duffy has suggested that conjugal visits can be useful in reducing the frequency of prison riots. ${ }^{24}$ Columbus Hopper has described their role in reducing homosexuality in the Mississippi State Penitentiary. ${ }^{25}$ The benefit is indirectly accomplished through the strengthening and maintenance of the prisoner's marital bond. Donald Clemmer, in his study 26 of the prison community, discovered that prisoners who maintain ties with law abiding members of the society while in prison, have a much better chance for rehabilitation than prisoners who do not maintain such ties.

\footnotetext{
${ }^{23} \mathrm{Id}$. at 171.

24 C.T. Duffy, A Frank Discussion of the Prison Problem Nobody Talks About, This Week Magazine, Oct. 21, 1962 at 12.

25 C. Hopper, The Conjugal Visit at Mississippi State Penitentiary, 53 J. CRIM. L.C. \& P.S. 342 (1962).

26 D. Clemmer, Observations on Imprisonment as a Source of Criminality, $41 \mathrm{~J}$. CRIM. L. \& CRIMINOLOGY 311 (1950).
} 
The most pronounced reason for advocating conjugal visitation has been to mitigate homosexual tensions of the inmate population. Stanley Telega who is the Vice President of the Fortune Society, a national rehabilitative organization for ex-convicts, who is married and is the father of a young girl and is out of prison for more than seven years, states about prison homosexuality that:

Most homosexual acts in prison are done by inmates whose former and primary orientation was heterosexual. However, due to the imposed unisexual atmosphere, homosexual desires and acts developed.... Conjugal visits would help. . . maintain a heterosexual orientation for those who are concerned about homosexuality. It would also help to alleviate general tensions because sexual tensions turn into fights among the men, in order to find some release. ${ }^{27}$

Fran O'Leary, a staff member of Encounter, a New York City based drug prevention group, formerly an inmate of prisons in New York and California, rejects conjugal visiting because of an underlying disgust with the prison system, but nevertheless acknowledges that:

Among the emotional strains on your system, the most outstanding lies in your sexual frustration. The frustration in coping with your feelings manifests itself through homosexuality within the prison walls. There are no opportunities to act out heterosexual cravings ... hence there is a violent reaction to the frustration.

The sad and most troubling part of prison homosexuality is when it is non-consensual. Sexual assaults in prison are literally rampant epidemics. The non-consensual nature is a valid reason to propagate conjugal visitation as a realistic concept. Supporters of

27 Norman Eliot Kent, Legal and Sociological Dimensions of Conjugal Visitation in Prisons, 2(47) NEW ENG. J. PRISON. L, 58 (1975). 
conjugal visitation argue that it will not only reduce prison homosexuality and preserve family ties, but diminish the problems of prison officials as well. Some prison administrators have also suggested that conjugal visiting privileges would be an incentive factor that might improve prison discipline, while aiding the prisoner's lives. All these factors are encouragingly rehabilitative.

\section{Potential Consequences of Granting the Right}

Revisiting the legislation and creating room for prisoners to be awarded the right of conjugal visits is an arduous task. A number of obstacles hamper its effective implementation. One of these is the finances and administrative requirements to let inmates avail this facility. Innocent taxpayers would be burdened to enhance the lives of prisoners, which can be hard to explain.

Considering the overcrowded and understaffed Indian prisons, proper searches of the visitors would be tough to take care of. Single prisoners might feel discriminated against, on grant of conjugal rights to married offenders. This could invite unrest or incidences of violence.

Doing away with segregation would further open doors for abuse of process. Prison cells may soon turn into prostitution dens and that too at the state expense. Moreover, the possibility of corruption creeping in cannot be ignored. The underpaid jail staff may fall prey to offers of setting up prostitutes for jail inmates while others may even prostitute their own family members to earn favours from fellow inmates.

Owing to poor infrastructure, creating space for conjugal visits within the existing prisons does not seem easy as well. Finally, it is argued by a critic that a prisoner truly repentant and unselfish would not subject his/ her spouse to the conditions under which conjugal visits must be practiced. Sex is, or should be, a private matter. The sexual relationship must take place in the sanctity of the house and not in a prison cubicle. ${ }^{28}$

28 Joseph K. Balough, Conjugal Visitations in Prisons: A Sociological Perspective, 28 FED. PROBATION. J, 57 (1964). 
In a nutshell, these are more of moral considerations or administrative inefficiencies rather than based on sound logic. This calls for a well calculated and cautious implementation, to suit the public morality concerns of a society like ours.

\section{Conclusion}

In a multidimensional society like India, there exist two different countries within one. We have our own traditions, customs, social values, apprehensions and anathemas. When we engage ourselves in academic and intellectual debates on issues such as 'gay-rights' and the recognition of 'third-gender', we can neither avoid nor can hide beneath our moral cover in the realistic aspect of conjugal visitation. It is high time that the stake holders sit together to deliberate upon the legislative or executive policy regime and recommend changes keeping in view of the futuristic priorities towards national cohesion.

The fact that needs to be acknowledged is that inmates do not lose their sexuality once they are imprisoned and regulating these interactions forms an essential part of what the correctional department should do. Apposite intervention in such interactions will not only ensure the safety of the inmates and staff with regard to incidents of sexual violence, but also assist in the realization of correctional goals and rehabilitation of inmates in true terms. Much work still remains to be done to outline a workable and humane approach in enhancing opportunities for inmate's sexual expression. This is only an initial step in that direction.

It is unreasonable to expect that prisoners check their sexuality at the prison gate. To deny conjugal visit is subjecting innocent family members to punishment. It invites continued unrest. Allowing conjugal visitations will make those concrete walls much more rehabilitative, less frustrating and a little more humane. Conjugal visitation is no wonder drug and is indeed not meant to be, but it may be a right of which prisoners are wrongfully deprived of as a consequence of their incarceration; a right that should be restored without any further delay. 